\author{
What Drives the Shadow Banking \\ System in the Short and Long Run? \\ John V. Duca \\ Federal Reserve Bank of Da llas \\ Research Department \\ Working Paper 1401
}




\title{
What Drives the Shadow Banking System in the Short and Long Run?
}

\author{
John V. Duca* \\ Associate Director of Research and Vice President \\ Research Department, Federal Reserve Bank of Dallas \\ P.O. Box 655906, Dallas, TX 75265 \\ (214) 922-5154, john.v.duca@dal.frb.org \\ and \\ Adjunct Professor, Southern Methodist University, Dallas, TX
}

February 2014

This paper analyzes how risk and other factors altered the relative use of short-term business debt funded by the shadow banking system since the early 1960s. Results indicate that the share was affected over the long-run not only by changing information and reserve requirement costs, but also by shifts in the impact of regulations on bank versus nonbank credit sources - such as Basel I in 1990 and reregulation in 2010. In the short-run, the shadow share rose when deposit interest rate ceilings were binding, the economic outlook improved, or risk premia declined, and fell when event risks disrupted financial markets.

JEL Codes: E44, E50, N12

Key Words: Shadow Banking, Regulation, Financial Frictions, Credit Rationing

* I thank Elizabeth Organ and Michael Weiss for comments, J.B. Cooke for excellent research assistance and for their comments on a summary of earlier and less complete findings in this paper, participants at the $16^{\text {th }}$ Annual International Banking Conference, Shadow Banking: Within and Across National Borders, co-sponsored by the Federal Reserve Bank of Chicago and the International Monetary Fund. The views expressed are those of the author and are not necessarily those of the Federal Reserve Bank of Dallas or the Federal Reserve System. 


\section{Introduction}

Credit funded through the "shadow banking system"-whether nonbank loans funded with uninsured debt or directly issued paper typically bought by money funds-has become more significant over time. As Figure 1 shows, the share of short-term debt of nonfinancial corporations funded by commercial paper and nonbank loans has roughly doubled since the late 1960s, and netting out commercial paper directly issued by nonfinancial corporations, there have been large shifts in the share of debt intermediated by nonbank financial firms. ${ }^{1}$ This is important because commercial paper and debt issued by nonbank financial firms are both vulnerable to financial market shocks and can be procyclical, as reflected in the sharp post-2007 drop in shadow bank lending and as emphasized in several recent papers by Adrian and Shin (2009a, 2009b, 2010), Geanakoplos (2010), and Gorton and Metrick (2012), inter alia. For these reasons, the size of the shadow banking system and its reaction to liquidity shocks make the real economy vulnerable to credit shortages stemming from flights to quality, which may not be fully offset by banks, especially if correlated loan losses impair the capital adequacy of bank and nonbank financial firms, as occurred in the 2008 crisis.

Disparate strands of the literature imply that the extent to which business finance is funded through securities markets has evolved, reflecting the long-run effects of regulatory arbitrage and financial innovations, as well as short-run financial market shocks. Combining these insights could provide a more cohesive framework for understanding both the long-run evolution and short-run variation in the relative importance of shadow banking. Such financial architecture models could help inform not only short-run policy responses to financial crises, but also the long-run design of financial systems that balance the gains from sound financial

\footnotetext{
${ }^{1}$ The security-funded share plotted in Figure 1 internalizes substitution between commercial paper directly issued by nonfinancial firms and credit to nonfinancial corporations.
} 
Figure 1: The Relative Importance of the Shadow Banking System as Tracked by the Security-Funded Share of Short-Run Nonfinancial Business Credit

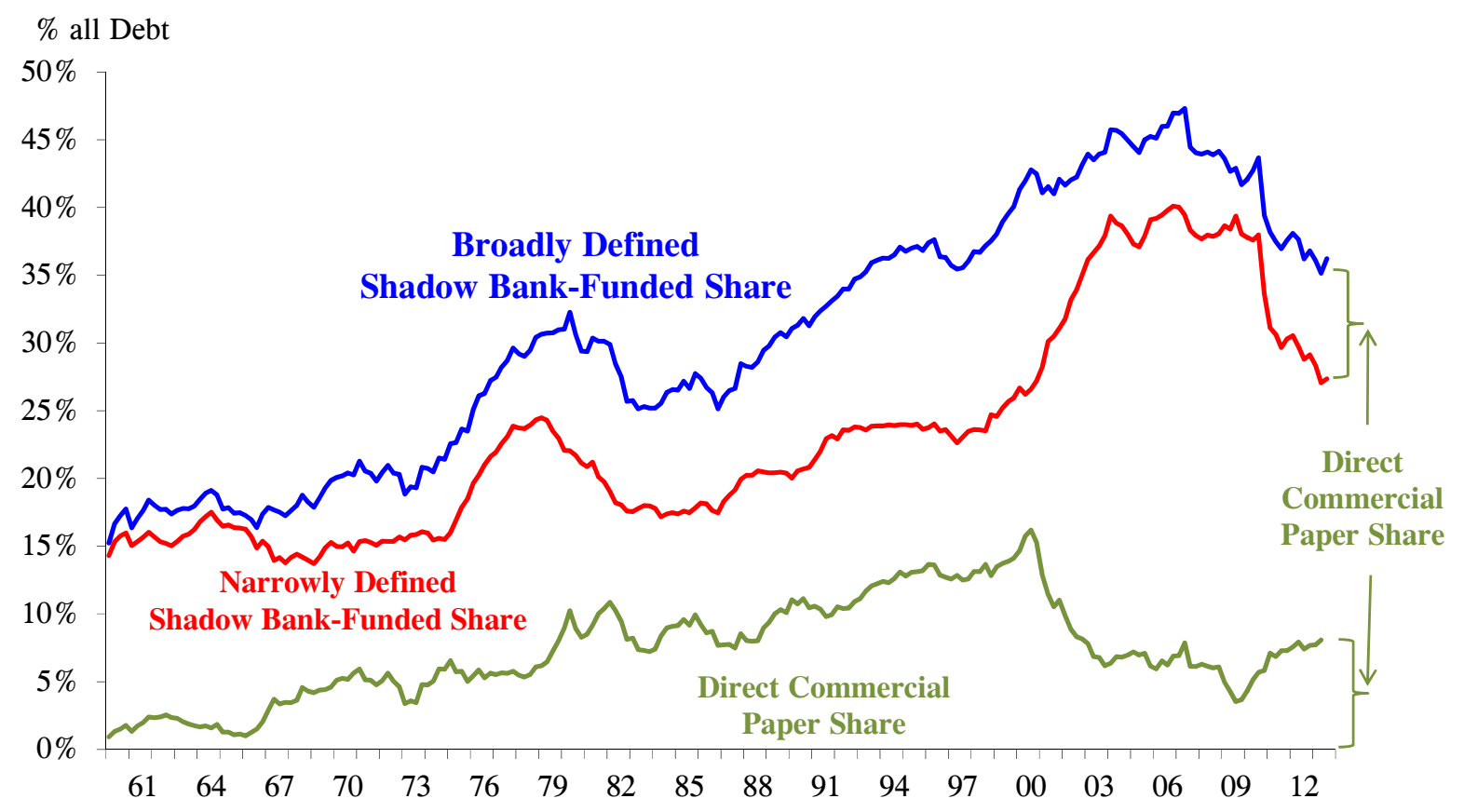

innovations with the need for some financial stability. Filling a gap in the literature, this paper empirically models the relative use of short-run nonfinancial corporate debt funded by securities markets, in both the short and long-runs, using a half-century of data.

This study is organized as follows. Section 2 provides a brief literature review of the factors that affected the composition of short-run business finance over the past several decades. Building off these insights, Section 3 presents an estimable, empirical specification for modeling the relative reliance of nonfinancial firms on shadow-funded debt share. Section 4 reviews the empirical results using quarterly data since the early 1960s. Findings are interpreted in Section 5, which draws parallels with the experience of the 1930s.

\section{Literature Review}

The existing literature on nonbank finance has mentioned several factors behind the rise of shadow banking over the past decades. Some older studies emphasize how reserve and other 
regulatory requirements encourage the use of alternatives to bank loans (e.g., Kanatas and Greenbaum (1982), Bernanke and Lown (1991), Berger and Udell (1994) and Duca (1992)) and the rise of securitization going back to at least Pennacchi (1988). Also contributing to the longrun rise are changes in information costs, which though mentioned in some studies (e.g., Edwards and Mishkin, 1995), have been rarely empirically assessed.

In the short-run, credit can shift from risky to safer borrowers if default risk rises or the cost of funds rises, owing to higher liquidity risk premiums (e.g., Bernanke and Blinder, 1988; Bernanke and Gertler, 1989; Bernanke, Gertler, and Gilchrist, 1996; Duca, 2013b; Jaffee and Russell, 1976; Keeton, 1979; Lang and Nakamura, 1995; and Stiglitz and Weiss, 1981). Newer studies find that movements in the spreads between investment grade corporate and Treasury interest rates mainly reflect swings in liquidity risk and risk aversion (Friewald, et al., 2012).

More recent literature has emphasized the vulnerability of financial firms and the financial system to liquidity risk (Adrian and Shin, 2009a, 2009b, 2010). Consistent with these theories, the experience of the Great Depression indicates that security-funded sources of external finance, such as commercial paper, are vulnerable to the jumps in risk premia typical of financial crises (Duca, 2013b). Indeed, real commercial paper outstanding fell 85 percent between July 1930 and May 1933 when spreads between corporate and Treasury bond yields jumped, accompanied by a rise in the relative and absolute use of bankers acceptances (BAs), a more liquid and collateralized money market instrument than un-backed commercial paper. ${ }^{2}$

Recent experience suggests that surges in risk premiums can be countered by central bank asset purchases that cushion the supply of security-funded credit to top-rated borrowers

\footnotetext{
${ }^{2}$ BAs are time drafts drawn on banks to finance the shipment or storage of goods. Banks guarantee payment to BA owners, making BAs tradable as investors know more about banks than goods buyers. The latter receive credit to pay sellers from banks, which fund credits by selling BAs. Goods collateralize BAs for banks. This contrasts with the unbacked commercial paper of the Great Depression era and more recent asset-backed commercial paper that is backed by paper assets whose values fell after 2006. Using ratios of BAs and commercial paper abstracts from other factors.
} 
(see Anderson and Gascon (2009), Duca (2013a), and Duygan-Bump, et al. (2013) on the Fed's commercial paper facility, and Goodhart (1987) on the need for a broad lender of last resort). For example, real commercial paper fell 74 percent during the 25 months between July 1930 and August 1932, but by a less dramatic 44 percent between July 2007 and August 2009. In contrast to the 1930s, the Federal Reserve used several asset purchase programs to limit surges in risk premia on high-grade commercial paper and residential mortgage-backed securities. Some of the smaller decline in commercial paper in the recent crisis also reflects the stronger macroeconomic policy response relative to the Great Depression.

Despite the limited literature on policy actions intended to counter the Great Recession, there has been little econometric analysis of what factors contributed to the rise of shadow banking before the recent crisis and its more recent partial retrenchment, likely reflecting several challenges. One is how to measure the shadow banking system, whose earlier rise was bolstered mainly by increased securitization of residential mortgages (see Pozar, et al, 2010, 2012) and a greater role of shadow banks in funding business. To avoid or limit the difficulties with blending household and business borrowing, as well as credits of mixed duration, this study focuses on the relative importance of shadow banks in funding short-run business credit. Using a half-century of data, the role of several potential factors — not just the latest fad — are assessed, and the sample is extensive enough to disentangle short- from long-term effects. By not being limited to the Great Moderation era, the time series analysis draws from experience spanning different regulatory regimes, which may provide more perspective on recent attempts at financial reform.

This study assesses how the relative importance of the shadow banking system is affected by short- and long-run factors stemming from regulatory burdens and information costs, drawing on insights from Kashyap, Wilcox, and Stein (1993) on the role of commercial paper in short-run 
business finance and Oliner and Rudebusch (1995) regarding the broad-based rather than narrow-based (bank) view of the credit channel of monetary policy. The models use data from the Federal Reserve's Financial Accounts of the U.S., covering a broad range of credit funded with commercial paper and other market debt. The relative use of credit funded by commercial paper (e.g., commercial paper and nonbank loans funded by securities issued by finance companies and asset-backed securities (ABS) lenders) versus bank-intermediated credit reflects the advantages of avoiding bank regulations (e.g., reserve and capital requirements, as in Greenbaum and Kanatas, 1982) relative to the advantages of banks having information and transactions cost advantages in lending and funding sources that are less exposed to the effects of shifting risk premia in securities markets.

For these reasons, movements in the relative use of security- or shadow-funded credit could reflect the combination of influences stressed in (1) older literature that emphasizes how reserve and other regulatory requirements encourage the use of alternatives to bank loans (e.g., Kanatas and Greenbaum, 1982); (2) the asymmetric information literature that models the composition of lending (e.g., Diamond, 1991, Jaffee and Modigliani, 1969, and Kashyap, Wilcox, and Stein, 1993); (3) the theoretical and empirical literature on the securitization of bank loans (e.g., Pennacchi, 1988); and (4) a newer literature examining the role in the recent financial crisis of procyclical liquidity premia and leverage (e.g., Adrian and Shin (2009a, 2009b, 2010), Geanakoplos (2010), and Gorton and Metrick (2012)). With regard to the fourth strand of literature, lenders' ability to fund loans with debt—whether through securitization by banks or by ABS entities - depends critically on how much collateral investors demand or equivalently how much leverage markets will allow lenders. In their model of lending funded without insured deposits, Schleifer and Vishny (2010) theoretically show that such lending can dry up if 
investors demand higher risk premia, a point that Adrian and Shin (2009a,b) empirically demonstrate and that Adrian and Shin (2010) analyze in a more market-oriented context.

\section{Model Specification and Data}

\section{IIIA. Modeling the Relative Use of Security Market-Funded Versus Deposit-Funded Loans}

For several reasons, this paper empirically models the shadow bank share of short-term debt for nonfinancial corporations - that is, funded directly from commercial paper and indirectly from nonbank financial intermediaries. First, much of this commercial paper is held by money market mutual funds, a type of shadow bank whose importance grew out of efforts to circumvent the burden of bank regulation (regulatory arbitrage). Second, the shadow bank share internalizes substitution between commercial paper directly issued by nonfinancial corporations and credit intermediated by nonbank financial intermediaries (Figure 1). This substitution became pronounced following the rise and fall of structured finance; usage of the shadow banking system increased following the passage of the Commodity Futures Modernization Act (CFMA) of 1999, which made many derivatives contracts outside of currency and interest-rate swaps enforceable (Roe, 2011; Stout, 2008), and then plunged after the passage of the DoddFrank (DFA) financial reform act in 2010, which partially leveled the regulatory playing field between commercial and shadow banking. Third, modeling the relative use of shadow bank funding is hampered by the unavailability of complete data on various funding sources, particularly in the financial sector and the unincorporated business sector. For this reason, modeling the structure of external finance for nonfinancial corporations is more feasible. Fourth, another challenge is controlling for the substitutability of different maturities of debt and between debt and equity financing. 
To limit such distortions and measurement error issues, this paper focuses on modeling the security market-funded share of short-term nonfinancial corporate debt, which is also referred to as the shadow bank share. Short-run debt tends to reflect working capital needs, rather than long-run investment needs, so there is no need to model volatile business fixed investment and thorny changes in the mix of debt and equity. Although the analysis does not measure the vulnerability of the financial system to funding from security markets versus that from insured deposits, it does assess the vulnerability of short-run nonfinancial corporate debt to nonbank sources. Although the noncorporate and financial corporate sectors are not modeled, it is useful to note that the nonfinancial corporate sector produces the vast bulk of U.S. GDP. Together, the aforementioned considerations indicate that modeling the short-run credit needs of nonfinancial corporations is both relevant and feasible.

The long-run relative use of shadow or security market-funded credit (SHADOW) can be modeled as a function of nonstationary ( $X$ vector) and stationary ( $Z$ vector) regulatory and risk variables reflecting the factors mentioned above. Short-run changes in $S H A D O W$ can be modeled as a function of an error-correction term $(E C \equiv$ actual minus equilibrium log-levels of SHADOW), short-run variables, and first-differences of any nonstationary $X$ components:

$$
\begin{aligned}
& \log (\text { SHADOW })=\lambda_{0}+\lambda_{1} \log (X)+\lambda_{2}(\mathrm{Z}) \\
& \Delta \log (\text { SHADOW })_{\mathrm{t}}=\alpha_{0}+\alpha_{1} \log (E C)_{\mathrm{t}-1}+\beta_{\mathrm{i}} \Delta \log (\text { SHADOW })_{\mathrm{t}-\mathrm{i}}+\theta_{\mathrm{i}} \Delta \log (X)_{\mathrm{t}-\mathrm{i}}+\delta Z_{\mathrm{t}} \\
& E C \equiv \log (\text { SHADOW })-\left[\lambda_{0}+\lambda_{1} \log (X)\right]
\end{aligned}
$$

This approach can be implemented with enough time series data. The only consistent, long-running time series source of data to track $S H A D O W$ into the recent period is the Federal Reserve Board's quarterly Financial Accounts (formerly, Flow of Funds). Higher frequency monthly data on commercial paper that span direct and asset-back commercial paper suffer from 
sample breaks and are consistently available only since 2001, making it difficult to identify longrun relationships because short-run trends may dominate sample periods of limited length.

\section{IIIB. Data and Variables}

Most of the determinants of the relative use of security- or shadow bank-funded credit reflect either information costs or regulatory arbitrage. For information costs, there are a handful of possible time series measures, whereas the regulatory arbitrage variables reflect the influence of several elements, most notably reserve requirement taxes, deposit regulations, and the relative burden of capital requirements on banks as opposed to nonbank financial intermediaries and securities markets. In addition to these more structural variables, short-run financial shocks can also be tracked. Following a description of how shadow banking is observed, the variables tracking its determinants are discussed in the order mentioned above.

\section{Relative Use of Shadow Bank or Security Market Funded Credit}

The relative use of securities-funded credit is analyzed using the variable SHADOW, which is a ratio based on quarterly Flow of Funds data on nonfinancial corporate debt since 1961:q4 (Figure 1). SHADOW equals the sum of directly issued commercial paper plus finance company loans plus other loans financed by asset-backed commercial paper (securitized commercial and industrial (C\&I) loans held by ABS issuers and loans to nonfinancial corporate businesses by ABS issuers) divided by the sum of directly issued commercial paper, bank loans and all other loans (the last category includes finance company loans and ABS-funded loans). The regression models start in 1963:q1, because shifts in underlying source data and sampling techniques created sample breaks in SHADOW during the late 1950s and early 1960s. ${ }^{3}$

\footnotetext{
${ }^{3}$ Including a dummy for a possible sample break in 1973q1 did not change the qualitative results and barely affected the estimated coefficients on other variables.
} 


\section{Long-Run Information and Transactions Costs}

In addition to regulatory arbitrage, the rise of shadow banking over recent decades partly stems erosion of banks' informational and transactions cost advantages over nonbanks, owing to improvements in technology (e.g., Edwards and Mishkin, 1995, and Mishkin, 2009). Studies of the rising importance of mutual funds emphasize the role played by declining transactions costs at nonbanks, which stem from improvements in overall financial sector productivity (Duca, 2000 and 2005). To parsimoniously model the influence of general declines in information costs, which likely capture declines in transactions costs, long-run models include a measure of information technology prices. Quarterly data on the implicit price deflator for information processing equipment were applied to the overall GDP chain price deflator to construct RPIT (Figure 3), a relative price measure that should be negatively related to the security-funded share of business credit because its declines should generally reflect the factors that reduce the informational and transactions cost advantages of bank over nonbank intermediaries.

\section{The Burden of Reserve Requirements}

The literature has long recognized that reserve requirements imposed a disadvantage on banks that spurred the growth of money market mutual funds and other alternatives to bank deposits (Kanatas and Greenbaum, 1982; Duca, 1992; and Rosengren, forthcoming). The reserve requirement tax can be proxied by nominal interest rates until the Fed started paying interest on reserves, in 2008:q4. However, the three-month T-bill rate (3monTR) was integrated of order 2 if substantial changes in reserve requirements are not taken into account..

A more precise measure calculates the reserve requirement $\operatorname{tax}(R R T A X)$ as the product of the three-month T-bill rate and the highest reserve requirement (Figure 2) on banks in central reserve city banks (large banks), with an adjustment for the advent of sweep accounts (Anderson 
Figure 2: Real Information Technology Costs and the Reserve Requirement Tax on Banks

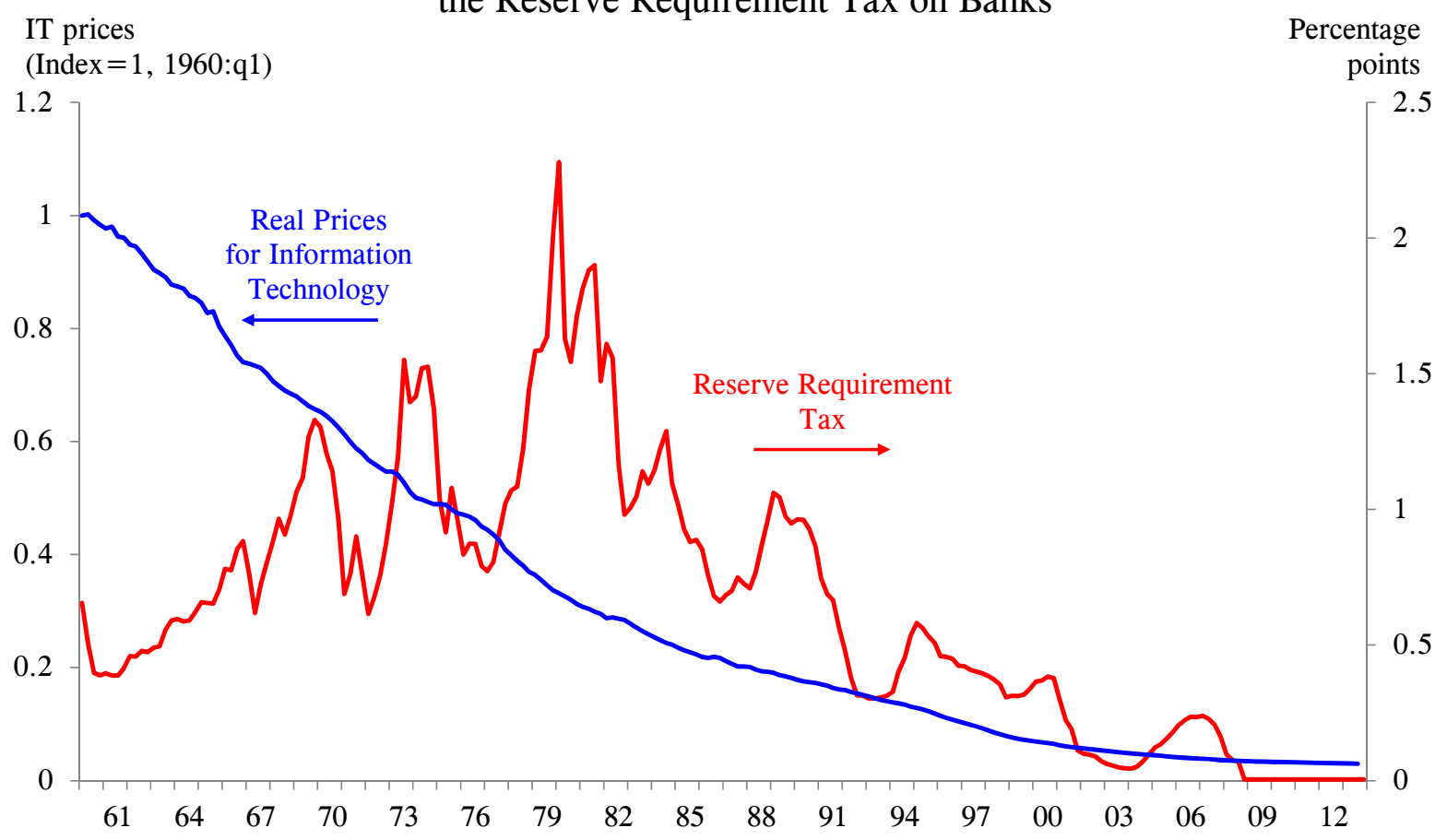

and Rasche, 2001; Dutkowsky and Cynamon, 2003) that shift balances overnight out of reservable checking accounts into money market deposit accounts (MMDAs) to avoid the reserve requirement tax. The adjustment equals one minus the ratio of swept balances to the sum of swept balances, reservable demand deposits, and reservable other checkable deposits (Federal Reserve Bank of St. Louis, 2010). The adjustment is consistent with the calculation of the reserve requirement tax in that the estimated reduction in required reserves balances of about 10 percent of sweep balances (St. Louis Federal Reserve Bank, 2010) roughly equals the maximum 10 percent marginal reserve requirement for large banks, the ratio gauging the reserve requirement tax. The reserve requirement tax equals 0.01 percent over 2008:q4 - 2011:q4 reflecting near zero short-term Treasury bill rates and the payment of similar interest on reserves. Reflecting the combination of all of these factors, the reserve requirement burden was high in the 1970s through early 1980s, but has since fallen to record low levels following the 
financial crisis (Figure 2). Changes in the reserve requirement tax, which were an impetus for the rise of shadow banking in the 1970s and early 1980s, have tempered the growth of shadow banking, particularly since the 2007 onset of the financial crisis.

\section{Deposit, Money Market Mutual Fund, and Credit Regulations}

During the era of Regulation Q ceilings on deposit rates that banks could offer, the institutions lost market share to commercial paper and security-funded lenders when market interest rates rose above deposit rate ceilings. The inability of banks to offer interest rates in line with market interest rates induced households and other investors to shift funds from banks, thereby encouraging banks to tighten their credit standards, consistent with the findings of Duca, Muellbauer, and Murphy (2012). One variable to track these effects on retail deposits is Duca's (1996) measure of how much Regulation Q ceilings on retail deposit interest rates were binding until Regulation Q ceilings were lifted in the early 1980s. REGQ controls for short-run disintermediation effects not tracked by interest rates or measures of the user cost of capital (Duca and $\mathrm{Wu}, 2009$ ), which are likely to increase the security-funded share of short-term business. REGQ also controls for the introduction of some semi-deregulated bank retail deposits in the late 1970 s (e.g., money market certificates and small saver certificates).

In addition to interest rate ceilings on retail deposits, there were ceilings on large-time deposits longer than 90 days until 1974:q2. Up through that quarter, the time series movements on bindingness of Regulation Q effects on large time deposits mirrored those of measures of the bindingness of Regulation Q on retail deposits. For this reason a separate bindingness measure for large time deposits was statistically insignificant in other runs not shown in Tables 1 or 2, as was a dummy for the lifting of deposit rate ceilings on large time deposits in 1974:q2. 
One innovation induced by deposit rate ceilings and reserve requirements was the creation of money market mutual funds (MMMFs) in 1971 in the U.S. that could pay marketdetermined interest rates. These funds were not really notable until about 1973, and checkwriting features on MMMFs for households were introduced in the late spring of 1974 by Fidelity Investments. By giving investors an option to purchase a more liquid form of commercial paper, the rise of money market funds lowered the costs of funding commercial paper and other forms of open market paper relative to banks. Partly to counteract this drain on the banking system, banks were allowed to offer MMDAs starting in 1982:q4. This resulted in inflows into bank deposits from both MMMFs and other assets that positively affected money demand (Duca, 2000) and the availability of bank loans (Aron, et. al, 2012).

To control for these two innovations in a parsimonious way, a variable (MMAdvantage) is included that equals 1 over 1974:q2-1982:q3, a period when security-funded business credit was positively affected by the presence of MMMFs and the absence of MMDAs. Because MMAdvantage enters as a long-run determinant of the t-1 lagged error-correction term, it is defined as equaling 1 in 1974:q2. In addition, two additional short-term impact variables are included. One (DMMMF) equals 1 in 1974:q2, -1 in 1974:q3, and 0 otherwise to control for the initial jump and fallback in the security-funded share around the introduction of MMMFs in 1974. The second impact variable (DMMDA) equals 1 in 1982:q4 and 0 otherwise.

Finally, another major short-term regulatory action affecting business financing sources was the imposition and lifting of bank credit controls in 1980:q2 and 1980:q3, respectively, which caused a short-lived shift of business finance to security markets in 1980:q2, which largely unwound in 1980:q3. To capture this short-run effect, models included $D C O N=1$ in 1980:q2, -1 in 1980:q3, and 0 otherwise. Reflecting its short-run, temporary influence on the 
structure of finance, DCON's inclusion did not affect other coefficient estimates or the qualitative results.

\section{The Relative Burden of Capital Requirements}

The literature has long emphasized how shadow banking has been affected by the relative burden of capital requirements on loans versus asset-backed securities held in bank portfolios or on bank versus nonbank assets (Kanatas and Greenbaum, 1982; Penacchi, 1988). The relative burden of required equity capital-to-asset ratios for business credit across commercial and investment banks differs across three periods, which can be tracked by the differential in minimum capital requirements for commercial bank and shadow bank credit at the margin.

Starting in 1981, commercial banks faced an official minimum 5 percent leverage ratio (see Wall and Peterson, 1987). The average capital equity-to-assets ratio for banks was around 6 percent between the early 1970s and again when the Basel I Accords were implemented in 1990, providing a cushion over regulatory minimums. From the early 1960 s to the early 1970 s, the ratio was around 7 percent. This, however, likely reflected the greater share of smaller bankswhose higher idiosyncratic risk likely induced higher cushions over unofficial required minimums - during a period that predated the partial consolidation of banking amid the rise of bank holding companies. ${ }^{4}$ Effectively, C\&I loans held in portfolio by large and medium-sized banks faced a 5 percent minimum capital ratio, whereas nonbank financial intermediaries faced no regulatory minimums and many investors could purchase commercial paper with no regulatory capital requirements imposed on them. In this era, the marginal regulatory capital differential between bank and shadow bank short-term credit was arguably 5 percentage points.

\footnotetext{
${ }^{4}$ Bank holding companies (BHCs) expanded in the late 1960s, aided by the Bank Holding Company Act of 1970, which took effect in mid-1971. Omarova and Tahyar (2011-2012, p. 148) note that the accompanying rise of BHCs was partly motivated by a desire to economize on equity capital held at individual banks owned by a BHC. This resulted in a minor decline in the banking industry's aggregate capital ratio from 7 percent in the 1960s to 6 percent by the early 1970 s.
} 
The implementation of Basel I in 1990 raised the capital requirement on most bank loans held in portfolio from 5 percent to 8 percent, encouraging the rise of shadow banking by inducing more securitization. ${ }^{5}$ Asset-backed securities were held either directly by investors or indirectly through money market and other mutual funds, and later by special investment vehicles (SIVs) during the height of the structured finance boom of the 2000s. Partly because the securitization of business loans was not highly developed at the time, Basel I had a role in the credit crunch of the early 1990s (see Bernanke and Lown, 1991, and Berger and Udell, 1994). Nevertheless, at the margins, Basel I effectively raised the gap between minimum capital ratio requirements for bank C\&I loans and shadow bank credit from 5 to 8 percentage points, thereby promoting the relative importance of shadow banking.

The regulatory playing field became less relatively conducive to shadow banking following the passage of the Dodd-Frank Act (DFA), which had three types of provisions relevant to modeling the shadow bank share of short-term business credit. First, the rules enacting this financial reform raised the minimum capital requirement on C\&I loans held in portfolio to 10.5 percent. Second, the act required banks to hold capital against losses of up to 5 percent on securitized assets and subjected them to regulatory stress tests that involved ensuring that banks maintained equity capital to withstand a scenario of severe recession and lower asset prices. The combination of these last two provisions essentially required loan originators to hold capital equal to 5 percent of securitized C\&I loans. On top of these capital requirements, banks are also required to build up in good times an additional 2.5 percent capital conservation buffer to protect their exposures to loans-both on- and off-balance sheet. At the margin, the combination of these provisions effectively narrows the difference between the minimum capital

\footnotetext{
${ }^{5}$ One motive for this was to promote mortgage securitization as a means of cushioning the availability of U.S. home mortgages following closure of many troubled savings and loan institutions in the late 1980s and early 1990s.
} 
ratios on C\&I loans held in portfolio and those securitized from 8 percent to 5.5 percent $(10.5$ percent on loans minus a 5 percent reserve on securitized C\&I loans). Not surprisingly, near the passage of DFA, the shadow bank share of short-term business credit underwent a sharp downward shift that has not reversed. ${ }^{6}$

This study parsimoniously tracks the shifts in capital regulatory arbitrage effects in an econometric framework with the variable CapDif (Figure 3), which equals the differential in minimum capital requirements for commercial bank and shadow bank credit at the margin. For the pre-Basel period when C\&I loan securitization was nonexistent, the marginal alternative to bank C\&I loans that faced a 5 percent minimum capital ratio were loans by finance companies and commercial paper that had no regulatory minimums, implying that CapDif should equal 5 percent. Between the enactments of Basel I and DFA, the margin of substitution shifted to a choice between bank loans held in portfolio facing an 8 percent minimum total capital ratio and securitized loans facing no capital minimums, which spurred the rise of ABS-financed bank loans and commercial paper. Accordingly CapDif equals 8 percent during this era. And in the DFA era, CapDif equals 5.5 percent to reflect the narrowing of the effective regulatory capital differentials between C\&I loans held in portfolio and those securitized by loan originators. Because the level of CapDif enters the error-correction models with a t-1 lag and the regulations it reflects were announced in advance of implementation, CapDif equals 5 up until 1989:q3, 8 between 1989:q4 and 2010:q3, and 5.5 starting in 2010:q4. ${ }^{7}$ To control for the short-run effects of DFA and pressure on financial institutions to conform quickly with it, a DFA implementation

\footnotetext{
${ }^{6}$ DFA toughened requirements on derivatives to improve their transparency, partly in an attempt to lower the systemic risk they create. That risk is seen as contributing to the rise of shadow banks and their role in the recent financial crisis (see Duca, et al., 2010). DFA also imposed minimum liquidity ratios on systemically important bank and nonbank financial firms that restrict not only their individual duration risk, but also (and perhaps more importantly) their associated systemic risks posed by asset maturity transformation (see Gorton and Metrick, 2012). ${ }^{7}$ A shift dummy for the SEC's easing of capital requirements on investment banks (equal to 1 from 2004:q4 to 2010:q3) was statistically insignificant and was not included in the models reported in Table 1.
} 
dummy (DFADUM) equal to 1 in 2010:q4 was also included (the inclusion of this dummy barely affects estimated long-run coefficients while tracking an unusual outlier).

\section{Tracking the Impact of Risk Premia and Procyclical Influences on Business Credit Sources}

The safety net for commercial banks tends to favor them over shadow banks during periods of economic distress and high risk premia. To control for such effects, two types of variables are included: forward-looking business cycle indicators and measures of liquidity and default premia. Of the former, the best performing real-time indicator is the spread between the 10-year and one-year Treasury yields $(Y C),{ }^{8}$ reflecting its usefulness as a leading economic indicator and perhaps for tracking incentives to "reach for yield" when short-term interest rates are low (Stein, 2013). The t-3 lag outperformed other lags, and this term premia outperformed

Figure 3: Tracking the Relative Impact of Capital Regulations on Banks and Shadow (Investment) Banks

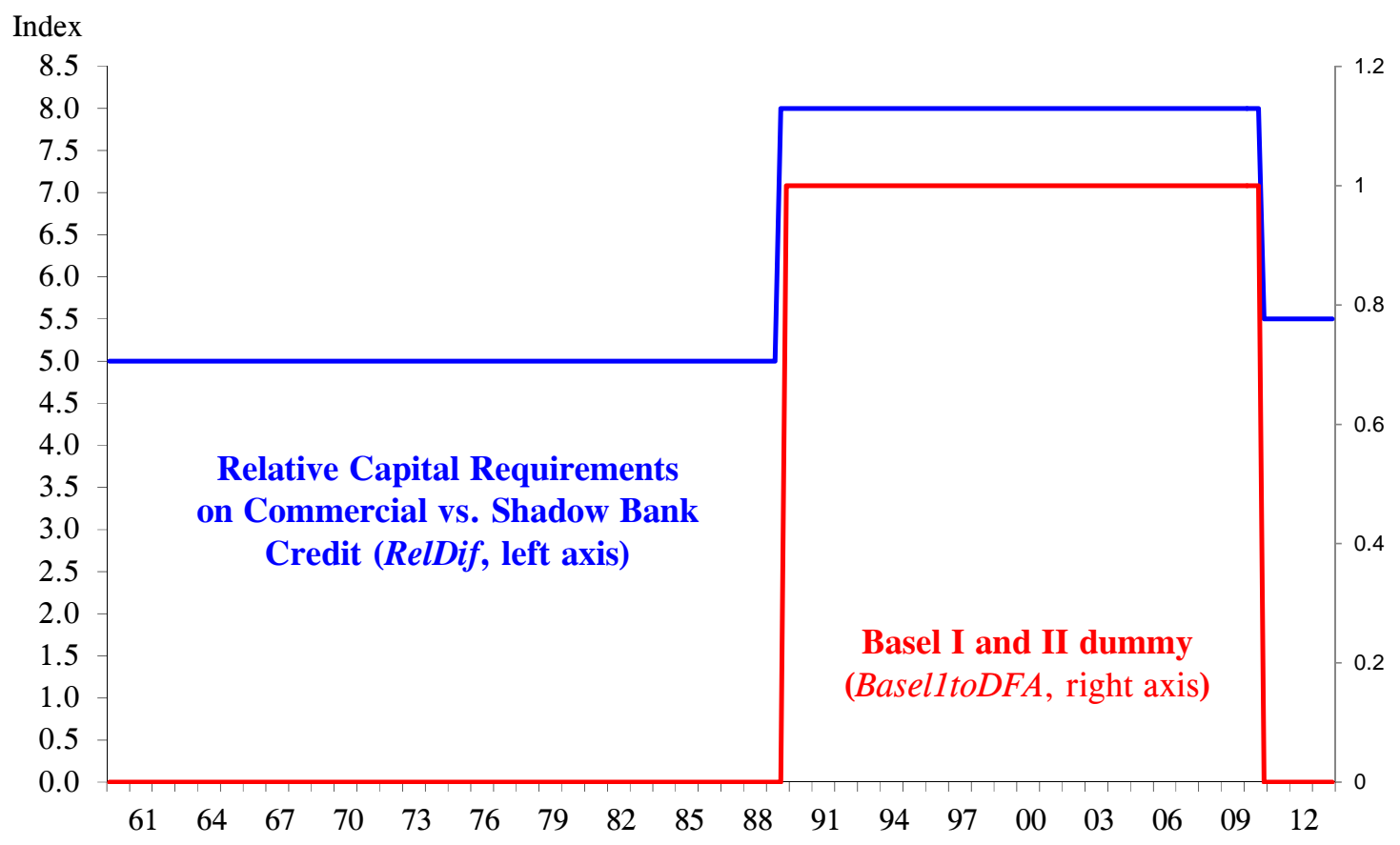

\footnotetext{
${ }^{8}$ The components of and weights on the index of leading economic indicators have changed so much over time that the index is not a real-time indicator, in contrast to the interest rates used to construct yield curve variables.
} 
those that replaced the one-year Treasury rate with either the federal funds rate or the threemonth Treasury rate.

Liquidity and default risk premia are tracked by spreads between yields on A-rated corporate and 10-year Treasury bonds (A10TR), consistent with evidence that such spreads reflect a combination of swings in default and liquidity risk premiums dating back to at least Jaffee (1975) and noted in more recent studies (e.g., Friewald, et al., 2012). Wider spreads are less of a threat to the funding of bank loans, as banks had access to insured deposits and Fed liquidity facilities before mid-October 2008. As a result, when such spreads are high, the price and non-price terms of market debt that typically funds shadow banks are high relative to those of bank loans, implying a negative relationship between the shadow bank share and bond spreads consistent with the negative relationships seen between commercial paper and bond spreads during the Great Depression (Duca (2013b)) and Great Recession (Duca (2013b)). A10TR outperformed the yield spread between Baa-rated corporate and 10-year Treasury bonds, perhaps reflecting the relative thinness of trading in Baa-rated firms that at times may be on the verge of downgrading to below investment-grade status. A10TR can be consistently measured, unlike spreads between commercial paper and Treasury bill rates that have a series of breaks. A10TR also outperformed the TED spread (three-month Libor minus three-month Treasury bill rates), which was statistically insignificant in other runs. This could reflect that the TED spread may pick up a combination of general market risk premia as well as more specific shocks to commercial banks relative to other financial firms, implying an ambiguous effect on the shadow bank share.

Because liquidity spreads may not track all flights to quality, a set of dummy variables for special events affecting business finance sources were included in some but not all 
regressions. Among these were a dummy, PennCentral, equal to 1 in the quarter when the Penn Central railroad declared bankruptcy and defaulted on its commercial paper, -1 in the next quarter when the flight to quality unwound, and 0 otherwise. ${ }^{9}$ A similarly structured discrete variable, StockCrash87, equals 1 when the stock market crashed in 1987:q4. Another event risk dummy was for the near outright default of New York City municipal debt in 1975:q4 (NYCDef $=1$ that quarter, 0 otherwise), which disrupted short-term debt markets in late 1975. The last discrete variable, $D B N P$, equals 1 in 2007:q4, typically seen as the start of the 2007-09 housing and financial crisis in the U.S., which was triggered on August 9 when three BNP hedge funds suspended redemptions because their subprime positions could not be priced to market values (Duca, Muellbauer, and Murphy, 2010). Of these event risk variables, three (PennCentral, NYCDef, and DBNP) are associated with disruptions that initially more notably affected shorterterm debt markets relevant for funding shadow banking and were not fully reflected in changes in corporate bond risk premia. The stock market crash of 1987 was a more general, albeit temporary, shock to the whole financial system as it initially raised fears that an economic depression might ensue. Because commercial banks have more explicit and comprehensive safety net support than shadow banks, tail risk events, such as stock market crashes, could conceivably induce investors to shift the composition of shorter-term asset holdings from uninsured debt into insured bank deposits or Treasury bills to an extent not fully reflected in corporate bond risk spreads. Accordingly, all four event risk variables are expected to have negative coefficients, reflecting temporary negative shocks to shadow bank funding.

\footnotetext{
${ }^{9}$ A similar dummy for the failure of the commercial bank Continental Illinois was insignificant in other runs.
} 


\section{Results for Modeling the Shadow Banking Share of Short-Term Business Credit}

Cointegration models of the security-funded short-run credit mix variable (SHAD) were run owing to unit roots in $S H A D$, the reserve requirement tax, the information technology price series, regulatory shift, and relative minimum capital ratio variables. ${ }^{10}$ Table 1 presents results from models using CapDif to track long-lasting capital regulatory shifts. Each model uses samples starting in 1963:q1 to avoid data distorted by sample breaks over 1959-61 stemming from changes in how the Financial Accounts of the U.S. sampled and measured balance sheet components. Models 1-3 and 5-6 are estimated over the full sample of 1963:q1-2013:q3, while model 4 estimates the preferred model (number 3) over the pre-crisis period of 1963:q1-2006:q4. Models 1-3 and 5 use different controls for short-run risk factors, while Model 6 replaces CapDif with a simple shift dummy for the Basel I to DFA era (BaseltoDFA).

Various combinations of short-run factors were tested and a sequential general-to-specific procedure for dropping the most insignificant short-run controls (such as those reported in the text or in footnotes) was adopted in constructing the preferred model, number 3 . In presenting the results, Table 1 adopts an ordering of models to illustrate the impact on a baseline model of adding short-run factors in building up to the preferred model, number 3.

As shown in Table 1, all six models include the reserve requirement tax and the real price of information technology as long-run endogenous variables in the cointegrating vector. Because the money fund and capital regulatory variables were long-lasting, they were included in the cointegrating vector to more accurately gauge long-run relationships. Each model, except for Model 6, contains a core and common set of short-run exogenous variables to handle general business cycle effects $(Y C)$, risk premia effects $(\ln (A T R 10))$, shorter-term regulatory effects involving disintermediation (REGQ), and impact dummies for the introduction of MMMFs,

\footnotetext{
${ }^{10}$ Unit root test statistics are provided at the bottom of Table 1.
} 
MMDAs, and the Dodd-Frank Act (DMMMF, DMMDA, and DFADum, respectively). Of these common variables, model 6 omits the yield curve and corporate bond premia variables.

The Johansen $(1991,1995)$ procedure is used to estimate cointegrating vectors for the log-level of $S H A D$ in the first stage, from which error-correction terms are constructed for use in a second-step VAR in first differences for modeling short-run movements (log first differences). For each model, unique and statistically significant cointegrating vectors are estimated, allowing for deterministic trends in the long-run variables but not in the cointegrating vector. In each model, a lag length of 5 was selected to maximize the Akaike Information Criterion subject to obtaining a unique vector and clean residuals.

In each model, significant, long-run coefficients indicate that regulations that disadvantaged banks (MMAdvantage and CapDif-but Basel1toDFA in model 6) increased the shadow banking system's share of business credit. Also, as expected, there is a negative relationship between the real price of information technology and the shadow bank share. Higher IT prices suggest that information is more costly and transactions costs are higher, ceteris paribus. By implication, informational and transactions cost advantages of bank over shadow bank credit are greater as IT prices are higher. In all models, the reserve requirement tax variable $(\ln R R T A X)$ has a positive and significant effect on the security market-funded share of short-term business credit. The coefficients on all of the long-run variables are reasonably similar across models 1-5, with long-run coefficients on the reserve requirement, information cost, and money fund/MMDA variables similar in model 6 . The models are robust to the inclusion of a variable tracking shift in capital regulation that either is (CapDif, in the tables) or is not (BaselItoDFA) calibrated for differences in effective capital ratios at the margin. 
The short-run models of the change in the shadow bank share account for long-run relationships by including an error-correction term equal to the t-1 gap of the actual securityfunded debt share minus the estimated long-run equilibrium. Across the short-run models in the lower-panel of Table 1, the error-correction coefficients are highly significant, with an expected negative sign. Thus, if actual shadow share exceeded its equilibrium in time $t-1$, this would exert a negative impact on the time $t$ change in the shadow share, as one would expect. In every model, the estimated speeds of adjustment are similar, implying that roughly 22 to 26 percent of disequilibria are eliminated on average per quarter. This speed is sensible given the large structural shifts in the security market-funded share of business credit over the past five decades.

Several noteworthy patterns of common short-run effects arise across the models. First, the Regulation Q variable is significant, with the bindingness of retail deposit ceilings having a highly significant and expected positive short-run effect on shadow bank share. Second, the introduction of MMMFs raised the shadow bank share, while the introduction of MMDAs and the passage of DFA had negative impacts. Third, as expected the yield curve (YC) is highly significant and positively signed and the bond spread is significant with a negative sign.

The first three models differ in how they control for changes in some types of short-run factors. To Model 1, Model 2 adds the dummy for the credit controls imposed on commercial banks in 1980:q2, which has a highly significant and positively signed coefficient. Other coefficients were not notably affected by this change, as seen by comparing Models 1 and 2. To Model 2, model 3 adds the four risk event variables for the Penn Central bankruptcy, the near explicit default of New York City in 1975, the stock market crash of 1987, and the BNP hedge fund event of August 2007. As could be expected, each of these event risk variables is significant, with the shadow bank share of short-term business credit swinging by three 
percentage points in response to the Penn Central default and by a larger six to seven percentage points in response to the near-default of New York City, the 1987 stock market crash, and August 2007 BNP subprime event. A separate dummy for the failure of Lehman was statistically insignificant, perhaps reflecting that much of the effect was picked up by the sharp spike in the corporate bond spread at that time and because the lender of last resort actions of the Federal Reserve and Treasury buttressed shadow banking by supporting money market mutual funds and the commercial paper market (Duca, 2013b). While models 1-3 each have sensible short- and long-run properties, along with clean residuals, Model 3 is considered the preferred specification because it has the best model fit of these three models and more comprehensively accounts for event risks.

A challenge to incorporating regulatory regimes into time series models is that the coefficient estimates may not be robust to the samples used. While some of this is inevitable given the nature of regime shifts, it is important to assess the reliability of coefficient estimates. Balancing these two considerations, model 4 was re-estimated over the pre-crisis period of 1963:q1-2006:q4 (necessitating the omission of the DBNP and DFADum variables). Ending the sample in 2006:q4 avoids including observations near the August 2007 shock to financial markets, the rescue purchase of Bear Stearns by JPMorgan Chase in the spring of 2008; and the failure of Lehman in September 2008. Comparing models 3 and 4 reveals no difference in qualitative findings and small differences in estimated coefficients, implying that the preferred specification is robust to including the recent crisis.

As another robustness check, model 5 replaces the calibrated capital arbitrage variable CapDif with Base1ItoDFA, the simple shift dummy that equals 1 for the sample between the enactment of Basel I and the enactment of DFA. Although the fit is higher in Model 5, the 
qualitative findings hold up and there is little effect on estimates of other coefficients. The only slightly better performance of model 5 is consistent with the perception that DFA restrained shadow banking mainly by affecting the effective relative capital requirements on shadow versus commercial banks. Nevertheless, the more calibrated CapDif has the appeal of being less ambiguous than BaselItoDFA in how it tracks regulatory effects and perhaps more useful in predicting the effect of marginal changes in relative capital requirements.

Finally, model 6 re-estimates model 4 by omitting the yield curve and corporate bond spread variables from model 1. A longer lag length of 6 quarters was needed to obtain mixed evidence for a significant and unique cointegrating vector, which had similarly signed and significant estimated long-run coefficients with magnitudes generally near those of model 1. Nevertheless, model 6 has a markedly lower degree of fit than does model 1, with a much smaller corrected R-square (.22 versus .32) and a higher standard error (.022 versus .020). The contrast is starker comparing models 6 and 3 (R-squares of .22 versus .45 and standard errors of .022 versus .018 , respectively). The differences between models 6 and 1 highlight the importance of procyclicality and general liquidity shock effects on the relative size of shadow banking, while the additional differences between models 4 and 1 illustrate the large impact of event risks.

Using the estimates from the cointegrating vector in the preferred model 3, one can construct an implied equilibrium share of security-funded lending. As shown in Figure 4, the equilibrium series implied by model 3 lines up well with the actual log share and tends to slightly lead it, consistent with the sign of the t-1 lagged error-correction term. Since the estimates of the long-run cointegrating relationships are similar across models 1-4, the equilibrium levels would be similar had model 1, 2, or 4 been used. Model 5 also yields similar results. 


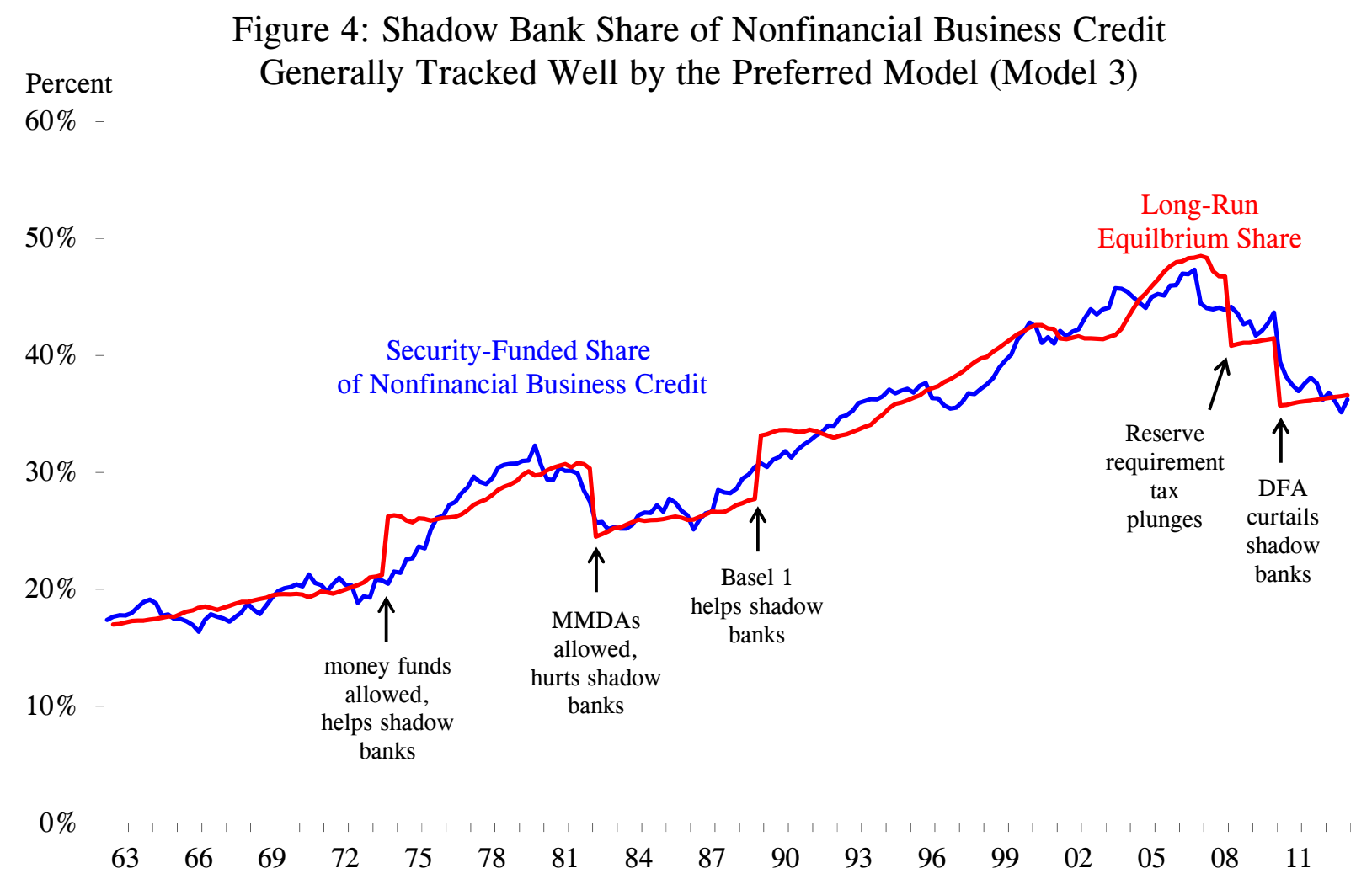

\section{Conclusion}

This study empirically analyzes what drove the long-run and short-run movements in the relative importance of shadow bank funding of the short-run credit of nonfinancial corporations over the past five decades. The share variable analyzed essentially captures the combined importance of the commercial paper market and nonbank financial intermediaries that comprise the shadow banking system. Consistent with several strands of the regulatory arbitrage literature, the long-run equilibrium share is negatively related to information costs and positively related to the absolute burden of bank reserve requirements and the relative burden of capital requirements on commercial versus shadow bank credit. Also in line with the shadow banking and money demand literature, the shadow bank share was also affected by the introduction of 
innovations, such as money market mutual funds, and deregulatory steps, such as the introduction of MMDAs.

In the short-run, the shadow bank-funded share not only fell when short-run liquidity premia were high, term premia reflected expectations of an improving economy, or event risks occurred in security markets, but also rose when deposit rate ceilings were more binding or short-run regulatory changes favored nonbank relative to bank finance. The former set of findings is consistent with the view that shadow banking is procyclical and vulnerable to liquidity shocks, as shown in Adrian and Shin (2009a, 2009b, 2010), Brunnermeier and Sannikov (2013), Geankoplos (2010), and Gorton and Metrick (2012). From a longer, more historical perspective, these results are also consistent with Bernanke (1983), pre-World War II studies of Kimmel (1939) and Young (1932), and related studies (Duca, 2009, 2013b) that find that during the Great Depression, the provision of credit shifted towards debt whose funding sources were less vulnerable to liquidity shocks.

The results of the current study have two general policy implications. First, the evidence indicates that shadow banking is very vulnerable to liquidity shocks and is very procyclical, raising issues for financial and macroeconomic stability. Because DFA has made it more difficult for the Federal Reserve to quickly stabilize financial markets with interventions such as buying commercial paper, these results support arguments favoring reform of the money market mutual fund industry to make it more resilient against liquidity and other financial shocks (e.g., McCabe, et al. (2013) and Rosengren (forthcoming)). Second, by imposing skin-in-the-game risk exposures to securitized assets and by applying stress tests to systemically important banks and nonbanks, DFA helped level the regulatory playing field between commercial and shadow 
bank credit, limiting one aspect of regulatory arbitrage while tightening financial regulation. ${ }^{11}$ In this respect, DFA has addressed one of the earlier shortcomings of the Basel I accords. In doing so, it has induced a retrenchment in the relative size of the shadow banking system's participation in providing short-run business credit.

From a broader perspective, the findings illustrate the need to synthesize roles for information costs, financial regulation, innovation, and risk when analyzing the evolution of the relative use of traditional deposit funded loans and nontraditional sources of credit as stressed in various strands of the money and banking literature (e.g., Adrian and Shin (2009a,b), Edwards and Mishkin (1995), Kanatas and Greenbaum (1982), Kashyap, Wilcox, and Stein (1993), and Pennacchi (1988), inter alia). By developing a financial architecture model of shadow banking's role in short-term business finance and using it to empirically assess the influence of different factors over the past half-century, the current study helps address one of the gaps in the shadow banking literature and hopefully will indirectly contribute to future studies as well.

\footnotetext{
${ }^{11}$ This statement is not an overall assessment or evaluation of DFA, which is beyond the scope of this study.
} 


\section{References}

Adrian, Tobias and Hyun S. Shin (2010), "Liquidity and Leverage," Journal of Financial Intermediation, 19, 418-37.

Adrian, Tobias and Hyun S. Shin (2009a), "Money, Liquidity, and Monetary Policy," American Economic Review 99(1), 600-09.

Adrian, Tobias and Hyun S. Shin (2009b), "The shadow banking system: implications for financial regulation,” Banque de France Financial Stability Review 13, 1-10.

Anderson, Richard B. and Charles S. Gascon (2009), "The Commercial Paper Market, the Fed, and the 2007-2009 Financial Crisis," Federal Reserve Bank of St. Louis Review 91(6), November/December, 589-612.

Anderson, Richard B. and Rasche, Robert (2001), "Retail Sweep Programs and Bank Reserves, 1994-1999," Federal Reserve Bank of St. Louis Review 83(1), January/February, 51-72.

Aron, Janine, Duca, John, Muellbauer, John, Murata, Keiko, and Murphy, Anthony (2012), "Credit, Housing Collateral and Consumption in the UK, U.S., and Japan," Review of Income and Wealth 58, 397-423.

Berger, Allen, and Gregory Udell (1994), "Did Risk-based Capital Allocate Credit and Cause a 'Credit Crunch' in the United States?” Journal of Money, Credit and Banking 26, 585628.

Bernanke, Ben S. (1983), "Non-Monetary Effects of Financial Crises in the Propagation of the Great Depression," American Economic Review 71, 257-76.

Bernanke, Ben S., and Blinder, Alan S. (1988), "Credit, Money, and Aggregate Demand," American Economic Review 78, 435-39. 
Bernanke, Ben S. and Mark Gertler (1989), "Agency Costs, Net Worth, and Business Fluctuations," American Economic Review 79, 14-31.

Bernanke, Ben S., Gertler, Mark, and Simon Gilchrist (1996), "The Financial Accelerator and the Flight to Quality," Review of Economics and Statistics 58, 1-15.

Bernanke, Ben S., and Cara S. Lown (1991), "The Credit Crunch," Brookings Papers on Economic Activity 1991:2, 205-39.

Brunnermeier, Markus K. and Yuliy Sannikov (2013), “The I Theory of Money,” manuscript, Princeton University, October.

Diamond, Douglas W. (1991), "Monitoring and Reputation: The Choice Between Bank Loans and Directly Placed Debt," Journal of Political Economy 91, 689-721.

Duca, John V. (1999), “An Overview of What Credit Market Indicators Tell Us,” Economic and Financial Review, Federal Reserve Bank of Dallas, 1999:Q3.

Duca, John V. (2000), "Financial Technology Shocks and the Case of the Missing M2," Journal of Money, Credit, and Banking 32, 820-39.

Duca, John V. (2013a), “Did the Commercial Paper Funding Facility Prevent a Great Depression Style Money Market Meltdown?” Journal of Financial Stability 9, 747-758.

Duca, John V. (2013b), "The Money Market Meltdown of the Great Depression," Journal of Money, Credit, and Banking 45, 493-504.

Duca, John V. (2005), "Why Have Households Increasingly Relied on Mutual Fund Loads to Own Equity?" Review of Income and Wealth 51 (3), 375-96.

Duca, John V., Muellbauer, John, and Murphy, Anthony (2010), "Housing Markets and the Financial Crisis of 2007-2009: Lessons for the Future,” Journal of Financial Stability 6, 203-17. 
Duca, John V., Muellbauer, John, and Anthony Murphy (2012), "How Financial Innovations and Accelerators Drive Booms and Busts in U.S. Consumption," mimeo, Oxford University.

Duca, John V. (1992), "U.S. Business Credit Sources, Demand Deposits, and the 'Missing Money,"' Journal of Banking and Finance 16, 567-83.

Duca, John V. (1996), “Deposit Deregulation and the Sensitivity of Housing,” Journal of Housing Economics 3, 207-227.

Duca, John V. and Anthony Murphy (2013), "Would a Bagehot Style Corporate Bond Backstop Have Helped Counter The Great Recession?” Economics Letters 119, 351-53.

Duca, John V. and Wu, Tao (2009), "Regulation and the Neo-Wicksellian Approach to Monetary Policy," Journal of Money, Credit, and Banking 41(3), 799-807.

Dutkowsky, Donald H. and Barry Z. Cynamon (2003), “Sweep Programs: The Fall of M1 and the Rebirth of the Medium of Exchange," Journal of Money, Credit, and Banking 35, 263-279.

Duygan-Bump, Burcu, Parkinson, Patrick M., Rosengren, Eric S., Suarez, Gustavo A. and Willen, Paul S. (2013), “How Effective Were the Federal Reserve Emergency Liquidity Facilities? Evidence from the Asset-Backed Commercial Paper Money Market Mutual Fund Liquidity Facility,” Journal of Finance 68, 715-37.

Edwards, Franklin R. and Frederic S. Mishkin (1995), “The Decline of Traditional Banking: Implications for Financial Stability and Regulatory Policy,” New York Federal Reserve Economic Policy Review 1 (2), July, 27-45.

Federal Reserve Bank of St. Louis (2010), "Federal Reserve Board Data on OCD Sweep Account Programs," $<$ http://research.stlouisfed.org/aggreg/swdata.html $>$

Friewald, Nils, Jankowitsch, Rainer, and Subrahmanyam, Marti (2012), "Illiquidity or 
Credit Deterioration: A Study of Liquidity in the Corporate Bond Market during Financial Crises," Journal of Financial Economics 105, 18-36.

Geanakoplos, John (2010) "The Leverage Cycle", in D.Acemoglu, K. Rogoff, and M. Woodford (eds.), NBER Macroeconomics Annual 2009, vol. 24, University of Chicago Press, Chicago, 2010, pp. 1-65.

Gilchrist, Simon and Egon Zakrajsek (2012), "Credit Spreads and Business Cycle Fluctuations," American Economic Review 102, 1692-1720.

Goodhart, Charles I. (1987), "Why Banks Need a Central Bank," Oxford Economic Papers 39(1), 75-89.

Gorton, Gary B. and Andrew Metrick (2012), "Securitized Lending and the Run on the Repo," Journal of Financial Economics 104, 425-51.

Jaffee, Dwight M., and Franco Modigliani (1969), “A Theory and Test of Credit Rationing," American Economic Review 59, 850-72.

Jaffee, Dwight M. (1975), “Cyclical Variations in the Risk Structure of Interest Rates,” Journal of Monetary Economics 1, 309-25.

Jaffee, Dwight M. and Thomas Russell (1976), "Imperfect Information, Uncertainty, and Credit Rationing," Quarterly Journal of Economics 90, 651-66.

Johansen, S. (1991), "Estimation and Hypothesis Testing of Cointegration Vectors in Gaussian Vector Autoregression Models," Econometrica 59, 1551-80.

Johansen, S. (1995), Likelihood-based Inference in Cointegrating Vector Autoregressive Models, Oxford: Oxford University Press.

Kanatas, George and Stuart I. Greenbaum (1982), "Bank Reserve Requirements and Monetary Aggregates," Journal of Banking and Finance 6, 507-20. 
Kashyap, Anil, Wilcox, David E, and Jeremy Stein (1993), "Monetary Policy and Credit Conditions: Evidence from the Composition of External Finance," American Economic Review 83, 78-98.

Keeton, William R. (1979), Equilibrium Credit Rationing, New York: Garland.

Lang, William W., and Nakamura, Leonard I. (1995), " 'Flight to Quality' in Bank Lending and Economic Activity," with William W. Lang, Journal of Monetary Economics 36, 145-64.

McCabe, Patrick E., Marco Cipriani, Michale Holsher, and Antoine Martin (2013), "Minimum Balance of 5 Percent Could Prevent Future Money Market Fund Runs," Brookings Papers on Economic Activity, Vol. Spring 2013, 211-78.

Mishkin, Frederic S. (2009), The Economics of Money, Banking, and Financial Markets, 9th Edition, Addison-Wesley: New York.

Oliner, Stephen D. and Glenn D. Rudebusch (1996), "Monetary Policy and Credit Conditions: Evidence from the Composition of External Finance: Comment," American Economic Review 86(1), 300-09.

Omarova, Saule T., and Margaret E. Tahyar (2011-2012), “That Which We Call a Bank: Revisiting the History of Bank Holding Company Regulation in the United States," Review of Banking and Financial Law 31, 113-99.

Pennacchi, George G. (1988), "Loan Sales and the Cost of Bank Capital," Journal of Finance 43 (2), 375-96.

Pozar, Zoltan, Tobias Adrian, Adam Ashcraft, and Hayley Boesky (2010 and 2012, revised), "Shadow Banking," Federal Reserve Bank of New York Staff Report No. 458.

Roe, Mark J. (2011), “The Derivatives Market's Payment Priorities as Financial Crisis Accelerator," Stanford Law Review 63, 539-90. 
Rosengren, Eric S. (forthcoming), "Our Financial Structures-Are They Prepared for Financial Stability?" Journal of Money, Credit, and Banking.

Schleifer, Andrei and Robert W. Vishny (2010), "Unstable Banking,” Journal of Financial Economics 97, 306-18.

Stein, Jeremy C. (2013), "Overheating in Credit Markets: Origins, Measurement, and Policy Responses," speech at the "Restoring Household Financial Stability after the Great Recession: Why Household Balance Sheets Matter," research symposium sponsored by the Federal Reserve Bank of St. Louis, St. Louis, Missouri, February 7, 2013. $<$ http://www.federalreserve.gov/newsevents/speech/stein20130207a.htm $>$

Stiglitz, Joseph E. and Andrew Weiss (1981), "Credit Rationing in Markets with Imperfect Information,” American Economic Review 71, 393-410.

Stout, Lynn A. (2008), "Derivatives and the Legal Origin of the 2008 Credit Crisis," Harvard Business Law Review 1, 1-38.

Wall, Larry D. and David R. Peterson (1987), "The Effect of Capital Adequacy Guidelines on Large Bank Holding Companies,” Journal of Banking and Finance 11, 581-600. 
Table 1: Quarterly Error-Correction Models of the Change in the Shadow Bank (Security-Funded) Share of NonFinancial Corporate Short-Term Debt

A. Long-Run Equilibrium Relationships: $\ln S H A D O W=\lambda_{0}+\lambda_{1} \ln R R T A X+\lambda_{2} \ln R P I T+\lambda_{3} M M a d v+\lambda_{2} C a p D i f$

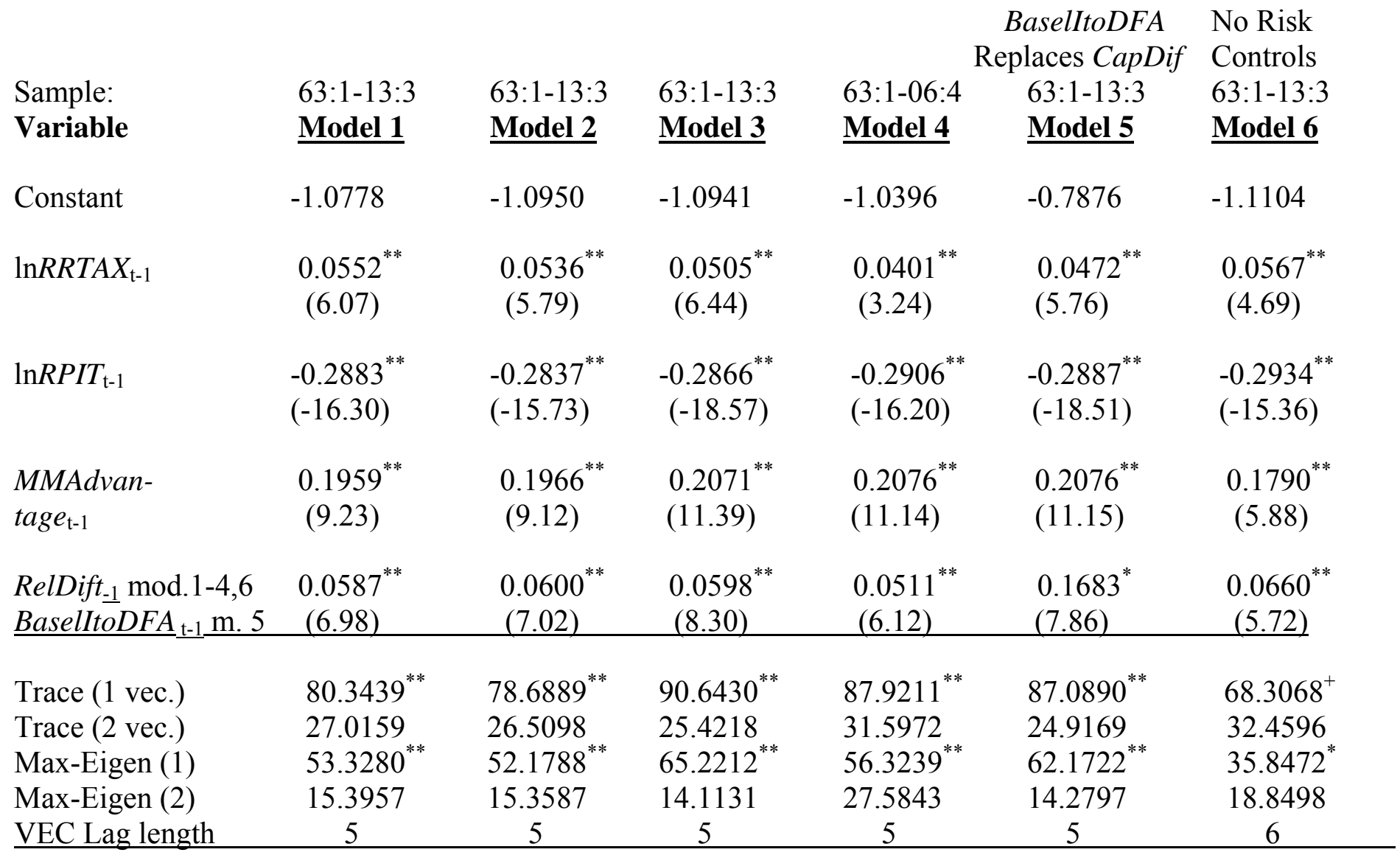

\section{B. Short-Run Equilibrium Relationships}

$\Delta \operatorname{lnSHADOW} W_{\mathrm{t}}=\alpha_{0}+\alpha_{1} \log (E C)_{\mathrm{t}-1}+\beta_{\mathrm{i}} \Delta \log (S H A D O W)_{\mathrm{t}-\mathrm{i}}+\theta_{\mathrm{i}} \Delta \log (X)_{\mathrm{t}-\mathrm{i}}+\delta Y_{\mathrm{t}}$

\begin{tabular}{|c|c|c|c|c|c|c|}
\hline Variable & Model 1 & Model 2 & Model 3 & Model 4 & Model 5 & Model 6 \\
\hline Constant & $\begin{array}{c}-0.0119^{*} \\
(-2.49)\end{array}$ & $\begin{array}{c}-0.0117^{*} \\
(-2.49)\end{array}$ & $\begin{array}{c}-0.0096^{*} \\
(-2.20)\end{array}$ & $\begin{array}{c}-0.0106^{*} \\
(-2.08)\end{array}$ & $\begin{array}{c}-0.0093^{*} \\
(-2.15)\end{array}$ & $\begin{array}{l}0.0040 \\
(0.90)\end{array}$ \\
\hline$E C_{\mathrm{t}-1}$ & $\begin{array}{c}-0.2241^{* *} \\
(-6.12)\end{array}$ & $\begin{array}{c}-0.2160^{* *} \\
(-5.99)\end{array}$ & $\begin{array}{c}-0.2469^{* *} \\
(-6.99)\end{array}$ & $\begin{array}{c}-0.2593^{* *} \\
(-6.59)\end{array}$ & $\begin{array}{c}-0.2425^{* *} \\
(-6.86)\end{array}$ & $\begin{array}{c}-0.1439^{* *} \\
(-4.09)\end{array}$ \\
\hline
\end{tabular}

\section{Regulatory Controls}

$\begin{array}{lcccccc}R E G Q_{\mathrm{t}-2} & 1.4024^{* *} & 1.3513^{* *} & 1.3189^{* *} & 1.3037^{* *} & 1.2921^{* *} & 0.6833^{*} \\ (\mathrm{x} 100) & (4.14) & (4.04) & (4.28) & (3.98) & (4.24) & (2.18) \\ & & & & & \\ D_{C C O N} & & 0.0365^{*} & 0.0377^{* *} & 0.0417^{* *} & 0.0379^{* *} \\ & & (2.50) & (2.82) & (3.01) & (2.84)\end{array}$




\begin{tabular}{|c|c|c|c|c|c|}
\hline Variable & $\underline{\text { Model } 1}$ & \multicolumn{4}{|c|}{ Regulatory Controls (continued) } \\
\hline$D M M M F_{\mathrm{t}-1}$ & $\begin{array}{c}0.0507^{*} \\
(2.24)\end{array}$ & $\begin{array}{l}0.0521^{*} \\
(2.33)\end{array}$ & $\begin{array}{l}0.0561^{*} \\
(2.74)\end{array}$ & $\begin{array}{l}0.0582^{* *} \\
(2.71)\end{array}$ & $\begin{array}{l}0.0562^{* *} \\
(2.75)\end{array}$ \\
\hline$D M M D A_{\mathrm{t}-1}$ & $\begin{array}{c}-0.0597^{* *} \\
(-2.71)\end{array}$ & $\begin{array}{l}-0.0613^{* *} \\
(-2.82)\end{array}$ & $\begin{array}{c}-0.0597^{* *} \\
(-3.00)\end{array}$ & $\begin{array}{c}-0.0682^{* *} \\
(-3.21)\end{array}$ & $\begin{array}{c}-0.0607^{* *} \\
(-3.05)\end{array}$ \\
\hline$D F A D U M_{\mathrm{t}}$ & $\begin{array}{c}-0.1120^{* *} \\
(-5.28)\end{array}$ & $\begin{array}{l}-0.1127^{* *} \\
(-5.40)\end{array}$ & $\begin{array}{c}-0.1127^{* *} \\
(-5.88)\end{array}$ & & $\begin{array}{l}-0.1162^{* *} \\
(-6.07)\end{array}$ \\
\hline & & \multicolumn{4}{|c|}{ Risk Controls } \\
\hline $\ln A T R_{\mathrm{t}-1}(\mathrm{x} 100)$ & $\begin{array}{c}-0.8273^{*} \\
(-2.30)\end{array}$ & $\begin{array}{c}-0.6667^{+} \\
(-1.89)\end{array}$ & $\begin{array}{c}-0.8762^{* *} \\
(-2.67)\end{array}$ & $\begin{array}{c}-0.9172^{* *} \\
(-2.44)\end{array}$ & $\begin{array}{l}-0.7943^{*} \\
(-2.43)\end{array}$ \\
\hline$Y C_{\mathrm{t}-3}(\mathrm{x} 100)$ & $\begin{array}{l}1.1381^{* *} \\
(5.46)\end{array}$ & $\begin{array}{l}1.0827^{*} \\
(5.26)\end{array}$ & $\begin{array}{l}1.0404^{* *} \\
(5.48)\end{array}$ & $\begin{array}{l}1.0719^{* *} \\
(4.73)\end{array}$ & $\begin{array}{l}1.0355^{* *} \\
(5.55)\end{array}$ \\
\hline$D B N P_{\mathrm{t}}$ & & & $\begin{array}{l}-0.0603^{* *} \\
(-3.19)\end{array}$ & & $\begin{array}{c}-0.0602^{* *} \\
(-3.19)\end{array}$ \\
\hline StockCrash87 & & & $\begin{array}{c}-0.0748^{* *} \\
(-3.80)\end{array}$ & $\begin{array}{l}-0.0766^{* *} \\
(-3.76)\end{array}$ & $\begin{array}{c}-0.0736^{* *} \\
(-3.74)\end{array}$ \\
\hline PennCentral ${ }_{\mathrm{t}}$ & & & $\begin{array}{c}-0.0317^{*} \\
(-2.42)\end{array}$ & $\begin{array}{c}-0.0317^{*} \\
(-2.39)\end{array}$ & $\begin{array}{l}-0.0315^{*} \\
(-2.41)\end{array}$ \\
\hline NYCDef & & & $\begin{array}{c}-0.0596^{* *} \\
(-2.93)\end{array}$ & $\begin{array}{c}-0.0566^{* *} \\
(-2.65)\end{array}$ & $\begin{array}{c}-0.0574^{* *} \\
(-2.82)\end{array}$ \\
\hline
\end{tabular}

\section{Lagged First Differences of Long-Term Variables}

$\begin{array}{lllllll}\Delta \ln S H A D O W_{\mathrm{t}-1} & \begin{array}{l}0.0890 \\ (1.32)\end{array} & \begin{array}{l}0.1000 \\ (1.50)\end{array} & \begin{array}{l}0.1693^{* *} \\ (2.70)\end{array} & \begin{array}{l}0.1600^{*} \\ (2.24)\end{array} & \begin{array}{l}0.1557^{*} \\ (2.49)\end{array} & \begin{array}{l}0.1014 \\ (1.37)\end{array} \\ \Delta \ln S H A D O W_{\mathrm{t}-2} & \begin{array}{l}0.1658^{*} \\ (2.49)\end{array} & \begin{array}{l}0.1619^{*} \\ (2.47)\end{array} & \begin{array}{l}0.1791^{* *} \\ (2.94)\end{array} & \begin{array}{l}0.1993^{*} \\ (2.92)\end{array} & \begin{array}{l}0.1812^{* *} \\ (2.97)\end{array} & \begin{array}{l}0.1774^{*} \\ (2.47)\end{array} \\ & & & & & & \\ \Delta \ln R R T A X_{\mathrm{t}-1} & -0.0070 & -0.0075 & -0.0072 & -0.0188 & -0.0068 & 0.0025 \\ & (-0.97) & (-1.06) & (-1.11) & (-1.13) & (-1.04) & (0.35) \\ \Delta \ln R R T A X_{\mathrm{t}-2} & 0.0024 & 0.0033 & 0.0012 & -0.0053 & 0.0024 & 0.0113 \\ & (0.33) & (0.48) & (0.19) & (-0.30) & (0.36) & (1.54) \\ \Delta \ln R P I T_{\mathrm{t}-1} & -0.2733 & -0.3071 & -0.2505 & -0.3502^{+} & -0.2651 & -0.2623 \\ & (-1.27) & (-1.45) & (-1.28) & (-1.65) & (-1.35) & (-1.12)\end{array}$


Variable

Model 1

$\underline{\text { Model } 3}$

Model 4

$\underline{\text { Model } 5}$

Model 6

Lagged First Differences of Long-Term Variables (continued)

\begin{tabular}{|c|c|c|c|c|c|c|}
\hline$\Delta \ln R P I T_{\mathrm{t}-2}$ & $\begin{array}{r}0.0242 \\
(0.10)\end{array}$ & $\begin{array}{l}0.0823 \\
(0.34)\end{array}$ & $\begin{array}{l}0.1550 \\
(0.69)\end{array}$ & $\begin{array}{l}0.2259 \\
(0.93)\end{array}$ & $\begin{array}{l}0.2299 \\
(1.03)\end{array}$ & $\begin{array}{c}0.0914 \\
(0.34)\end{array}$ \\
\hline $\begin{array}{l}\Delta M M A d a v a n- \\
\text { tage }_{\mathrm{t}-1}\end{array}$ & $\begin{array}{l}-0.0369^{+} \\
(-1.81)\end{array}$ & $\begin{array}{c}-0.0354^{+} \\
(-1.76)\end{array}$ & $\begin{array}{l}-0.0434^{*} \\
(-2.31)\end{array}$ & $\begin{array}{c}-0.0417^{*} \\
(-2.08)\end{array}$ & $\begin{array}{l}-0.0420^{*} \\
(-2.24)\end{array}$ & $\begin{array}{r}-0.0195 \\
(-0.91)\end{array}$ \\
\hline $\begin{array}{l}\Delta M M A d a v a n- \\
\text { tage }_{\mathrm{t}-2}\end{array}$ & $\begin{array}{l}0.0033 \\
(0.16)\end{array}$ & $\begin{array}{r}-0.0020 \\
(-0.10)\end{array}$ & $\begin{array}{r}-0.0101 \\
(-0.54)\end{array}$ & $\begin{array}{l}0.0149 \\
(0.76)\end{array}$ & $\begin{array}{r}-0.0096 \\
(-0.51)\end{array}$ & $\begin{array}{l}0.0067 \\
(0.31)\end{array}$ \\
\hline$\Delta$ RelCapital $_{\mathrm{t}-1}$ & $\begin{array}{r}-0.0023 \\
(-0.40)\end{array}$ & $\begin{array}{r}-0.0024 \\
(-0.42)\end{array}$ & $\begin{array}{r}-0.0047 \\
(-0.92)\end{array}$ & $\begin{array}{c}0.0081 \\
(1.25)\end{array}$ & $\begin{array}{l}0.0061 \\
(0.43)\end{array}$ & $\begin{array}{r}-0.0049 \\
(-0.80)\end{array}$ \\
\hline$\Delta$ RelCapital $_{\mathrm{t}-2}$ & $\begin{array}{r}0.0001 \\
(0.02) \\
\end{array}$ & $\begin{array}{l}0.0002 \\
(0.04) \\
\end{array}$ & $\begin{array}{r}-0.0002 \\
(-0.03) \\
\end{array}$ & $\begin{array}{l}0.0030 \\
(0.46) \\
\end{array}$ & $\begin{array}{r}-0.0076 \\
(-0.55) \\
\end{array}$ & $\begin{array}{r}-0.0030 \\
(-0.49) \\
\end{array}$ \\
\hline \multicolumn{7}{|c|}{ Summary Statistics } \\
\hline Adjusted $\mathrm{R}^{2}$ & .3220 & .3415 & .4480 & .3856 & .4485 & .2217 \\
\hline S.E. & 0.0204 & 0.0201 & 0.0184 & 0.0186 & 0.0184 & 0.0219 \\
\hline VECLM(1) & 18.24 & 16.51 & 14.30 & 14.49 & 13.42 & 21.73 \\
\hline $\operatorname{VECLM}(2)$ & 25.90 & 27.39 & 25.71 & 17.37 & 21.84 & $35.54^{+}$ \\
\hline VECLM(4) & 26.97 & 26.19 & 29.24 & 30.68 & 23.51 & 22.51 \\
\hline $\operatorname{VECLM}(6)$ & 15.51 & 15.93 & 31.46 & 36.73 & 29.16 & 19.20 \\
\hline
\end{tabular}

Unit Root Tests (1962:q1-2013:q3)

\begin{tabular}{|c|c|c|c|}
\hline & $\begin{array}{l}\text { Level (SIC lag } \\
\text { in parentheses) }\end{array}$ & $\begin{array}{l}\text { 5\% Critical } \\
\text { level for lag }\end{array}$ & $\begin{array}{l}\text { 1\% Critical } \\
\text { level for lag }\end{array}$ \\
\hline $\ln S H A D O W$ & -0.448450 & -3.431682 & -4.003005 \\
\hline nSHADO & $-5.174103^{* *}(7)$ & -3.431682 & -4.003005 \\
\hline $\ln R R T A X$ & $-1.192915 \quad(0)$ & -3.432005 & -4.003675 \\
\hline$\Delta \ln R R T A X$ & $-12.32873^{* *}(0)$ & -3.432005 & -4.003675 \\
\hline $\ln R P I T$ & 1.795024 & -3.432005 & -4.003675 \\
\hline$\Delta \ln R P I T$ & $-7.298104^{* *}(0)$ & -3.432005 & -4.003675 \\
\hline
\end{tabular}

Notes: ${ }^{+},{ }^{*}$, and ${ }^{* *}$ denotes significancet at the $90 \%, 95 \%$, and $99 \%$ level, respectively. t-statistics are in parentheses. A lag length of 4 minimized the AIC in models 1, 2, 5, and 6, and yielded unique, significant vectors allowing time trends in the variables and, in most cases, clean residuals. A lag length of 5 was used in models 3 and 4, and a lag length of 2 in model 7. Lag lengths for unit root tests are based on the SIC and all included a constant and a trend. Coefficients on lags of difference terms longer than $\mathrm{t}-2$ are omitted to conserve space. 